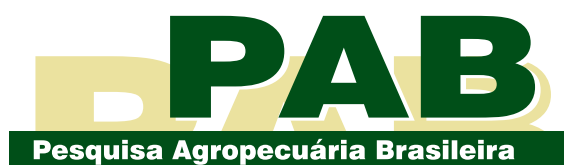

ISSN 1678-3921

Journal homepage: www.embrapa.br/pab

For manuscript submission and journal contents, access: www.scielo.br/pab

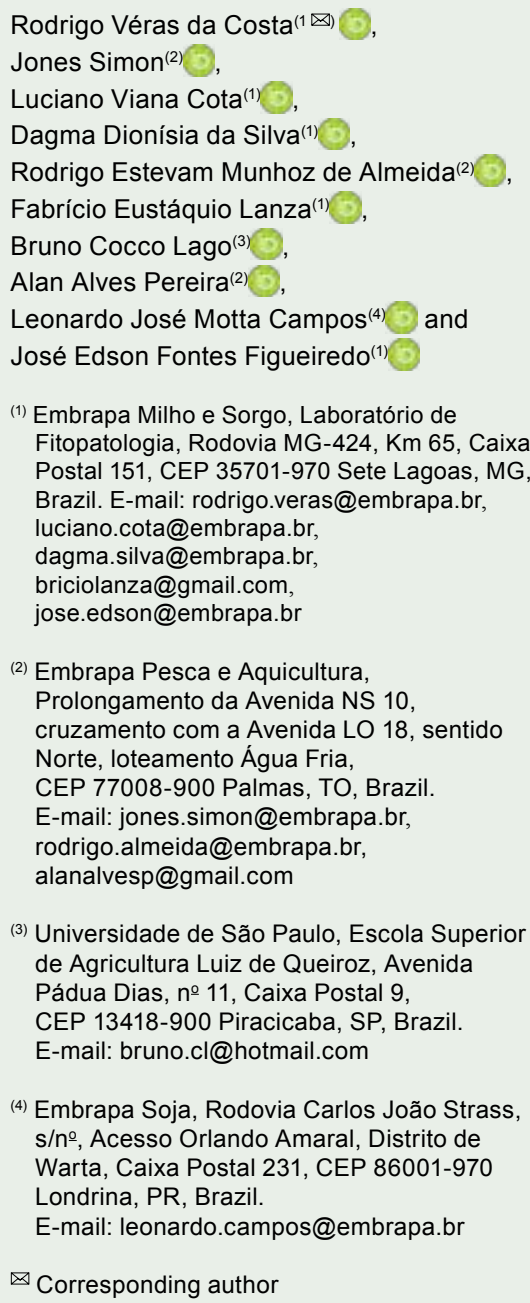

(3) Universidade de São Paulo, Escola Superior de Agricultura Luiz de Queiroz, Avenida Pádua Dias, n 11, Caixa Postal 9, CEP 13418-900 Piracicaba, SP, Brazil. E-mail: bruno.cl@hotmail.com

(4) Embrapa Soja, Rodovia Carlos João Strass, s/no, Acesso Orlando Amaral, Distrito de Warta, Caixa Postal 231, CEP 86001-970 Londrina, PR, Brazil.

E-mail: leonardo.campos@embrapa.br

$\bowtie$ Corresponding author

Received

November 3, 2017

Accepted

April 26, 2018

How to cite

COSTA, R.V. da; SIMON, J.; COTA, L.V.; SILVA, D.D.da; ALMEIDA, R.E.M.de; LANZA F.E.; LAGO, B.C.; PEREIRA, A.A.; CAMPOS, L.J.M.; FIGUEIREDO, J.E.F. Yield losses in off-season corn crop due to stalk rot disease. Pesquisa Agropecuária Brasileira, v.54 e00283, 2019. DOI: https://doi.org/10.1590/ S1678-3921.pab2019.v54.00283.

\section{Yield losses in off-season corn crop due to stalk rot disease}

\begin{abstract}
The objective of this work was to assess yield losses due to stalk rot in corn (Zea mays) hybrids, as well as to identify the main pathogenic fungi responsible for the disease during the off-season, in the state of Tocantins, Brazil. Two field experiments were carried out, one with five hybrids, in 2015, and another with four, in 2016. Ears of healthy and stalk rot-infected plants were collected from each plot, at harvest. Ear size, grain and ear weights, and grain moisture content were measured. From each diseased plant, a stalk piece with two to three nodes was removed for pathogen identification and quantification. The most common pathogens were: Fusarium graminearum, Stenocarpella maydis, and Macrophomina phaseolina. All yield parameters were significantly lower in stalk rot-infected plants, with average losses of $30.6 \%$, in 2015 , and of $34.3 \%$ in 2016 . The highest yield losses are observed in hybrids with the highest grain/ear weight ratio.
\end{abstract}

Index terms: Fusarium graminearum, Zea mays, lodging, stalk breakage, stem disease.

\section{Perdas na produtividade de milho safrinha em razão de podridões da base do colmo}

Resumo - O objetivo deste trabalho foi avaliar as perdas causadas pelas podridões da base do colmo em híbridos de milho (Zea mays), bem como identificar os principais patógenos causadores da doença, durante a safrinha, no Estado do Tocantins, Brasil. Foram realizados dois ensaios, um com cinco híbridos, em 2015, e outro com quatro, em 2016. Espigas de plantas sadias e doentes foram colhidas em cada parcela, por ocasião da colheita. Foram medidos tamanho de espigas, peso de grãos e espigas, e umidade dos grãos. De cada planta doente, foi retirado um fragmento do colmo com dois a três entrenós, utilizado para identificação e quantificação dos patógenos. Os patógenos mais comuns foram: Fusarium graminearum, Stenocarpella maydis e Macrophomina phaseolina. Todas as variáveis de produtividade foram significativamente menores nas plantas doentes, com perdas médias de $30,6 \%$, em 2015, e de 34,3\% em 2016. As maiores perdas são observadas em híbridos com maior relação entre pesos de grãos e espigas.

Termos para indexação: Fusarium graminearum, Zea mays, acamamento, quebramento do colmo, doenças de colmo.

\section{Introduction}

Stalk rot is one of the most important diseases of corn (Zea mays L.) worldwide (Gatch et al., 2002; Costa et al., 2008, 2010; Cota et al., 2012). It can be caused by many fungi and bacteria, which primarily infect senescing, injured, or stressed plants (Jackson-Ziems et al., 2014). Yield losses caused by stalk rot depend on the aggressiveness of the pathogens and the development stage of the plant (Scott \& 
Griffiths, 1980). Some pathogens, such as Fusarium spp., Colletotrichum graminicola, and Macrophomina phaseolina can colonize the stalk tissues of apparently healthy plants during the vegetative stage, causing reduced grain weight and severe yield losses (Casela et al., 2006; Costa et al., 2008). However, at the end of the reproductive cycle, after physiological maturity, stalk rot usually does not result in significant losses (Jackson-Ziems et al., 2014).

The main cause of yield losses due to stalk rot are the colonization and degradation of stalk vascular tissues by pathogens, hindering the translocation of water and nutrients to the plants (Christensen \& Wilcoxson, 1966; Denti \& Reis, 2003). Therefore, the premature death of plants, stalk breakage, and lodging are common in areas with a severe occurrence of the disease (Munkvold \& White, 1999; Reis et al., 2004).

Several studies have quantified the yield losses caused by stalk rot in corn planted in summer, i.e., in the first-season crop, under natural or artificial inoculation conditions. In Brazil, in the state of Paraná, yield losses from 12 to $40 \%$ (Nazareno, 1989) and of $27.3 \%$ in the state of Minas Gerais (Cota et al., 2012). However, there is no known information on yield losses due to stalk rot in corn hybrids grown in the off-season.

In the country, corn has been traditionally cultivated in summer, with sowing from October to November; therefore, researches have focused on this growing environment. However, in the last decades, there has been a marked growth of the corn crop cultivated in the off-season, between February and March. Currently, off-season corn corresponds to $69 \%$ of the cultivated area and to $68 \%$ of the total corn produced in Brazil (Acompanhamento..., 2018). In this context, studies have been carried out to identify better strategies and production systems for the off-season production environment, as well as potential for losses and more efficient measures for the management of pests, diseases, and weeds.

At present, it is well known that stalk rot is closely related to the occurrence of different types of stress during the crop cycle (Darrah et al., 2003). Certain stresses reduce the photosynthetic activity of plants, leading to changes in the translocation of photoassimilates, which reflects directly in grain filling (Dodd, 1980b). These stresses may result in early senescence and in the reduction of sugar transport to roots and stalks, which predisposes plants to fungal infections (Dodd, 1977).
Under the Brazilian climate, the risk of abiotic stresses occurring in the corn crop is greater during the off-season than in the first season. Indeed, the yield potential of corn grown in the off-season is strongly affected by several types of biotic and abiotic stresses, such as frost, drought, nutritional deficiency, and incidence and severity of pests and diseases (Cardoso et al., 2004; Arakaki \& Minuzzi, 2016). Therefore, further studies are necessary to assess the potentially greater yield losses caused by stalk rot diseases in the off-season crop.

The objective of this work was to assess yield losses due to stalk rot in corn hybrids, as well as to identify the main pathogenic fungi responsible for the disease during the off-season, in the state of Tocantins, Brazil.

\section{Materials and Methods}

In order to evaluate corn yield losses and the fungi associated with stalk rot during the off-season, field experiments were carried out in 2015 and 2016 in the experimental field of Brejinho farm, located in the municipality of Pedro Afonso, in the state of Tocantins, Brazil. According to Köppen-Geiger, the climate of the region is characterized by a rainy summer and a dry winter (Alvares et al., 2013). The average temperature is $32^{\circ} \mathrm{C}$ in the dry season, from April to September, and $26^{\circ} \mathrm{C}$ in the rainy season from October to March. The soil is classified as a Latossolo Vermelho distrófico (Santos et al., 2013), i.e., a Typic Haplustox. Sowing was carried out during the second season, under a no-tillage system, on straw from soybean [Glycine max (L.) Merr.] grown in summer. The experimental area was being used for agriculture for more than 15 years.

The experimental design was a randomized complete block with four replicates. In 2015 and 2016, treatments were arranged in a $5 \times 2$ and $4 \times 2$ factorial arrangement (hybrid x stalk rot), respectively. In 2015, the following hybrids were used: DKB 350 PRO, DKB 390 PRO, LG 6038 PRO, LG 6036 PRO, and Status VIP; sowing was carried out on 2/24/2015. In 2016, the used hybrids were: AG 8690 VT PRO 3, DKB 310 VT PRO 2, P30S31YH, and P3779H; sowing occurred on $2 / 25 / 2016$. In both years, the areas were previously cultivated with soybean in summer.

The plots were $10 \mathrm{~m}$ wide and $20 \mathrm{~m}$ long $\left(200 \mathrm{~m}^{2}\right)$, with a $0.5-\mathrm{m}$ distance between rows and a planting rate of three seeds per meter. Base fertilization and nitrogen 
were applied according to the soil chemical analysis. At harvest, healthy and stalk rot-infected plants were selected in each plot.

The identification of diseased plants consisted in removing the leaves from the stalk base, visually observing external symptoms (discolorations), and pressing the stalk with the thumb and index finger to determine the rigidity of the stalk tissues, as described by Casa et al. (2007). The identification and quantification of the pathogenic fungi species were carried out in the phytopathology laboratory of Embrapa Milho e Sorgo, in the municipality of Sete Lagoas, in the state of Minas Gerais, Brazil. For each hybrid, evaluations were performed in both healthy plants and in those infected with stalk rot.

For the morphological identification of Fusarium species, isolates were grown in BDA medium and incubated at $25^{\circ} \mathrm{C}$, under a 12 -hour photoperiod, for 14 days. Colony characteristics were analyzed with the support of a stereo and a compound microscope. The morphology of microconidia, macroconidia, conidiogenous cells (phallus), and chlamydospores was observed for each isolate, and the species were identified according to the criteria proposed by Leslie \& Summerell (2006). In Stenocarpella spp. and M. phaseolina, identification was done based on the morphological characteristics of conidia and conidiogenous cells, according to Sutton (1980).

Ears of seven stalk rot-infected and of seven healthy plants were collected from each plot and weighed separately. For each sample, the following were determined: ear length, in centimeters; grain weight per ear, in grams; and grain moisture, in percentage. Two or three internode segments of each diseased plant were used to identify and quantify the fungi species causing stalk rot. Small fragments from inside the stalk were aseptically removed, plated on oatmeal (Avena sativa L.) medium (Dhingra \& Sinclair, 1995), and incubated under continuous light at $25^{\circ} \mathrm{C}$, for three to four days prior to the identification of the pathogens. Incidence data of the fungi species in the samples were expressed as percentage. Data on grain weight per ear (GWear) and ear length (EL) were used to calculate losses regarding both of these traits in healthy and stalk rot-infected plants. A final population of 55,000 plants per hectare and an ear index equal to one were used to estimate the yield potential of the evaluated corn hybrids.

Potential yield, final yield, and yield losses were obtained using the following formulas: potential yield $\left(\mathrm{kg} \mathrm{ha}^{-1}\right)=$ GWear $\mathrm{x}$ final plant population $\mathrm{x}$ ear index; final yield $\left(\mathrm{kg} \mathrm{ha}^{-1}\right)=$ (GWear of healthy plants $\mathrm{x}$ number of healthy plants per hectare, NHP) + (GWear of diseased plants $\mathrm{x}$ number of diseased plants per hectare, NDP). The NDP was determined using an estimative of $30 \%$ plants affected by the disease per hectare; therefore: 55,000 x 0.3 (incidence of stalk rot) $=16,500$ plants per hectare. The NHP was estimated from the NDP: $55,000-16,500=38,500$ plants per hectare. Yield losses were obtained by subtracting the final yield from the potential yield.

Agronomic variables, productivity data, and incidence of stalk rot fungi were subjected to the analysis of variance, applied separately for each year, and means were compared by the Scott-Knott test, at $5 \%$ probability, when necessary.

For both years, water balance was calculated for the off-season corn crop, according to Rolim et al. (1998). The climatic data were obtained from a meteorological station belonging to Embrapa, installed in the experimental area.

\section{Results and Discussion}

In both experimental years, for the GWear variable, there was a significant interaction between hybrids and sanity. In addition, all yield variables were significantly lower in stalk rot-infected plants, compared with the healthy ones.

In 2015, temperature and rainfall conditions resulted in a positive water balance, with surplus soil moisture during great part of the corn growing season (Figure 1 A). This allowed for the development of plants without the occurrence of water stress during the critical phases of the crop. In the 2016 off-season, rainfall volume was above the historical average in January, but scarce in the subsequent months. Therefore, unlike in the previous year, temperature and rainfall conditions resulted in a negative impact on water balance, causing water deficit in the soil from February until the end of the corn growing season (Figure $1 \mathrm{~B}$ ). Consequently, the corn plants were subjected to long-term drought stress during crucial periods of plant development, primarily during the flowering stage.

A high incidence of stalk rot disease was also observed in both years, in most of the hybrids. The magnitude of the quantified losses evidences the importance of this disease as a limiting factor for the off-season corn crop. It should be noted that none of 
the hybrids showed resistance to stalk rot fungi under the studied conditions.

All productivity variables evaluated were reduced by disease incidence. GWear averages in healthy and diseased plants, respectively, were 204.5 and $141.2 \mathrm{~g}$, in 2015, and 184.9 and $121.3 \mathrm{~g}$ in 2016 (Table 1). Therefore, average losses in GWear were 30.6 and $34.3 \%$ in 2015 and 2016, respectively. Average ear size was reduced in approximately $17 \%$ in stalk rot-infected plants. These results were not compared with those of the literature since, up to date, there is no known information on losses due to the disease in the off-season, although losses in variables caused by stalk rot in the summer crop have been reported.

According to Denti \& Reis (2003), the incidence of stalk rot in corn in Southern Brazil varied from 40 to $45 \%$ between the $1997 / 1998$ and $1998 / 1999$ summer crop seasons, with average damages of 678 and $1,151 \mathrm{~kg} \mathrm{ha}{ }^{1}$, respectively. According to these authors, the greatest damages were observed in areas of corn monoculture, which allowed a fast increase in the inoculum potential of stalk rot fungi. Also in the Southern region of the country, Nazareno (1989) recorded stalk rot incidence ranging from 15 to $85 \%$, with yield losses from 12 to $40 \%$. In experiments with inoculation of $C$. graminicola on stalks of different corn hybrids, also in Brazil, Cota et al. (2012) verified an average reduction of 25.6 to $27.8 \%$ in grain weight.

In his classic work, White et al. (1979), after summarizing the results of several experiments, concluded that the magnitude of the losses due to stalk rot in corn yield are highly dependent on genotype and environmental conditions, as also verified in the present work. In 2015, the GWear average of LG 6036 PRO was significantly superior to that of the other hybrids (Table 1). The lowest GWear value was found for the DKB 350 hybrid, while the other ones did not differ significantly. The highest loss of $36.5 \%$ was verified for LG 6036 PRO, which differed significantly from the other hybrids (Table 1); and the lowest losses of 28.5 and $26.9 \%$ were obtained for Status VIP and DKB 350 PRO.

Up to now, efforts have been applied in the search for resistance to different fungi separately, including, for example, C. graminicola (Carson \& Hooker, 1981; Tomam Jr. \& White, 1993; Nicoli et al., 2016),

Table 1. Grain weight per ear (GWear), ear length (EL), grain moisture (GM) content, and GWear and EL losses of healthy and stalk rot-infected corn plants (Zea mays), in the 2015 and 2016 off-seasons ${ }^{(1)}$.

\begin{tabular}{|c|c|c|c|c|c|c|}
\hline \multirow[t]{2}{*}{ Treatment } & \multicolumn{2}{|c|}{ GWear (g) } & \multirow{2}{*}{$\begin{array}{l}\text { Ear length } \\
\quad(\mathrm{cm})\end{array}$} & \multirow{2}{*}{$\begin{array}{c}\text { Grain moisture } \\
(\%)\end{array}$} & \multicolumn{2}{|c|}{ Losses $(\%)$} \\
\hline & Healthy plants & Infected plants & & & GWear & EL \\
\hline & \multicolumn{6}{|c|}{2015 off-season } \\
\hline LG 6036 PRO & $231.0 \mathrm{Ca}$ & $146.7 \mathrm{Bb}$ & $13.8 \mathrm{~b}$ & $21.1 \mathrm{a}$ & $36.5 \mathrm{c}$ & $21.4 \mathrm{a}$ \\
\hline LG 6038 PRO & 207.2Ba & $143.3 \mathrm{Bb}$ & $14.2 \mathrm{~b}$ & $20.4 \mathrm{a}$ & $30.8 b$ & $19.8 \mathrm{a}$ \\
\hline DKB 390 PRO & $205.0 \mathrm{Ba}$ & $142.5 \mathrm{Bb}$ & $15.4 \mathrm{c}$ & $21.9 \mathrm{a}$ & $30.5 b$ & $21.5 \mathrm{a}$ \\
\hline Status VIP & $203.0 \mathrm{Ba}$ & $145.0 \mathrm{Bb}$ & $14.7 \mathrm{c}$ & $23.6 \mathrm{~b}$ & $28.5 \mathrm{a}$ & $18.9 \mathrm{a}$ \\
\hline DKB 350 PRO & $176.2 \mathrm{Aa}$ & $128.8 \mathrm{Ab}$ & $12.6 \mathrm{a}$ & $21.5 \mathrm{a}$ & $26.9 \mathrm{a}$ & $20.4 \mathrm{a}$ \\
\hline Healthy plants & - & - & $15.6 \mathrm{~b}$ & $23.1 \mathrm{~b}$ & & \\
\hline Infected plants & - & - & $12.7 \mathrm{a}$ & $20.2 \mathrm{a}$ & - & - \\
\hline \multirow[t]{2}{*}{ Coefficient of variation (\%) } & \multicolumn{2}{|c|}{9.2} & 5.7 & 4.5 & 9.1 & 6.3 \\
\hline & \multicolumn{6}{|c|}{2016 off-season } \\
\hline AG 8690 VT PRO 3 & $202.9 \mathrm{Ca}$ & $125.7 \mathrm{Ab}$ & $19.6 \mathrm{~b}$ & $13.2 \mathrm{~b}$ & $38.0 \mathrm{c}$ & $17.4 \mathrm{~b}$ \\
\hline DKB 310 VT PRO 2 & $183.9 \mathrm{Ba}$ & $120.1 \mathrm{Ab}$ & $16.4 \mathrm{a}$ & $13.7 \mathrm{~b}$ & $34.7 \mathrm{~b}$ & $12.6 \mathrm{a}$ \\
\hline P30S31YH & 177.7Aa & $116.7 \mathrm{Ab}$ & $20.0 \mathrm{~b}$ & $14.3 \mathrm{a}$ & $34.3 b$ & $18.2 \mathrm{~b}$ \\
\hline P3779H & $175.3 \mathrm{Aa}$ & $122.9 \mathrm{Ab}$ & $19.3 b$ & $14.4 \mathrm{a}$ & $30.0 \mathrm{a}$ & $17.9 \mathrm{~b}$ \\
\hline Healthy plants & - & - & $18.8 \mathrm{~b}$ & $14.5 \mathrm{~b}$ & & \\
\hline Infected plants & - & - & $15.9 \mathrm{a}$ & $13.2 \mathrm{a}$ & - & - \\
\hline Coefficient of variation (\%) & \multicolumn{2}{|c|}{3.5} & 3.2 & 4.1 & 3.9 & 7.6 \\
\hline
\end{tabular}

${ }^{(1)}$ Means followed by equal letters, uppercase in the columns and lowercase in the rows, do not differ by the Scott-Knott test, at 5\% probability. 
Gibberella zeae (Yang et al., 2010), Diplodia zeae (Kappelman \& Thompson, 1966), M. phaseolina (Diourte et al., 1995), and Pythium inflatum (Yang et al., 2005). However, the use of genetic resistance for the management of stalk rot is greatly hampered by the involvement of several fungi species and their concomitant occurrence in the field.

Furthermore, several studies have reported variability in the response of corn hybrids to the disease. According to Jackson-Ziems et al. (2014) and Vincelli \& Hershman (1985), stalk rot is more common and severe in more productive hybrids, which produce larger and heavier ears. During periods with reduced leaf area due to disease or water stress, heavier ears tend to "cannibalize" stalk carbohydrates, weakening tissues and predisposing them to stalk rot fungi. The results obtained in the present work are in alignment with those of the cited authors. In both experimental years, the greatest losses were observed in hybrids that presented the greatest productive potential, i.e., the greatest GWear. In 2015, the LG 6036 PRO hybrid, with the greatest GWear of $231 \mathrm{~g}$, had the greatest loss of $36.5 \%$ (Table 1). The lowest absolute GWear of $176.2 \mathrm{~g}$ was recorded for DKB 350 PRO, whose loss was also low, of 26.9\%. In 2016, the AG 8690 VT PRO 3 hybrid reached the highest GWear average of $202.9 \mathrm{~g}$, with a loss of $38 \%$. The P3779H hybrid had the lowest GWear mean of 175.3 and the lowest loss of $30 \%$.

There was no significant interaction between hybrids and sanity for the EL variable in any of the experimental years. The average reduction in ear size in stalk rot-infected plants was 18.6 and $15.4 \%$, in 2015 and 2016, respectively (Table 1). No correlation was observed between reduction in GWear and EL, since, in some hybrids, the heaviest ears were not the largest. According to Vincelli \& Hershman (1985), losses caused by stalk rot occur due to the premature death of plants, which results in lower grain filling and, consequently, in lighter grains. The results obtained in the present study are in agreement with these findings. This was the case for LG 6036 PRO, which had heavier but smaller ears, and for DKB 390 PRO, which had larger but lighter ears.

The greatest losses, therefore, were associated with hybrids that developed heavier ears, not larger ones. This fact was also evident when potential and final yield means were analyzed. The highest yield potential of $12,707 \mathrm{~kg} \mathrm{ha}^{-1}$ (Table 2) was achieved by the LG
6036 PRO hybrid, and the lowest of $9.692 \mathrm{~kg} \mathrm{ha}^{-1}$ by DKB 350 PRO. The other hybrids did not differ significantly. The same ranking was observed for final yield and yield loss. Therefore, losses were greater in hybrids that showed the greatest productive potential. These results are related to how stalk rot acts on plants, reducing grain filling and their cycle, which explains the more pronounced effect of stalk rot on hybrids with a greater productive potential.

According to Dodd (1980a), a greater number of grains or heavier ears represents an increase in drain size, resulting in agreater translocation of carbohydrates to ears in detriment of stalks and roots, predisposing the plants to stalk rot fungi. These fungi degrade vascular tissues, compromising the translocation of water and nutrients from soil to the shoot of plants, causing their premature death and decreases in their yield potential and grain quality (Casa et al., 2007; Khokhar et al., 2014). In the present study, the lower moisture content of the grains of infected plants (Table 1) indicates early senescence due to stalk rot fungi; on average, grain moisture content was reduced in $10 \%$ in infected plants.

Table 2. Potential yield, final yield, and yield losses of corn (Zea mays) hybrids due to stalk rot in experiments conducted in the 2015 and 2016 off-seasons ${ }^{(1)}$.

\begin{tabular}{lccc}
\hline Treatment & $\begin{array}{c}\text { Potential } \\
\text { yield }\end{array}$ & $\begin{array}{c}\text { Final } \\
\text { yield }\end{array}$ & $\begin{array}{c}\text { Yield } \\
\text { loss }\end{array}$ \\
& - & & \\
& & 2015 off-season \\
DKB 350 PRO & $9,692 \mathrm{a}$ & $8,909 \mathrm{a}$ & $782 \mathrm{a}$ \\
DKB 390 PRO & $11,278 \mathrm{~b}$ & $10,247 \mathrm{~b}$ & $1,031 \mathrm{~b}$ \\
LG 6038 PRO & $11,399 \mathrm{~b}$ & $10,345 \mathrm{~b}$ & $1,054 \mathrm{~b}$ \\
Status VIP & $11,169 \mathrm{~b}$ & $10,211 \mathrm{~b}$ & $957 \mathrm{~b}$ \\
LG 6036 PRO & $12,707 \mathrm{c}$ & $11,317 \mathrm{c}$ & $1,390 \mathrm{c}$ \\
\hline Mean & 11,249 & 10,206 \\
\hline & & 2016 off-season \\
P3779H & $9,641 \mathrm{a}$ & $8,674 \mathrm{a}$ & $863 \mathrm{a}$ \\
P30S31YH & $9,776 \mathrm{a}$ & $8,776 \mathrm{a}$ & $1,007 \mathrm{~b}$ \\
DKB 310 VT PRO 2 & $10,114 \mathrm{a}$ & $9,061 \mathrm{a}$ & $1,052 \mathrm{~b}$ \\
AG 8690 VT PRO 3 & $11,159 \mathrm{a}$ & $9,884 \mathrm{~b}$ & $1,272 \mathrm{c}$ \\
\hline Mean & 10,173 & 9,100 & 1,049 \\
\hline (1)Means followed by equal letters do not differ by the Scott-Knott test, at
\end{tabular}

Pesq. agropec. bras., Brasília, v.54, e00283, 2019 DOI: 10.1590/S1678-3921.pab2019.v54.00283 
The high productive potential and final yields observed in the present work exceed the values usually obtained in the off-season crops in the region. However, it should be pointed out that, for the purpose of this study, other causes of losses that normally occur in the off-season, such as those due to climatic stresses, pests, foliar disease, and nutritional deficiencies, were not considered.

In normal conditions, the main risk in off-season cultivation in the Brazilian Cerrado is related to water deficit, since the rainy season ends during the flowering and grain-filling stages. In these cases,
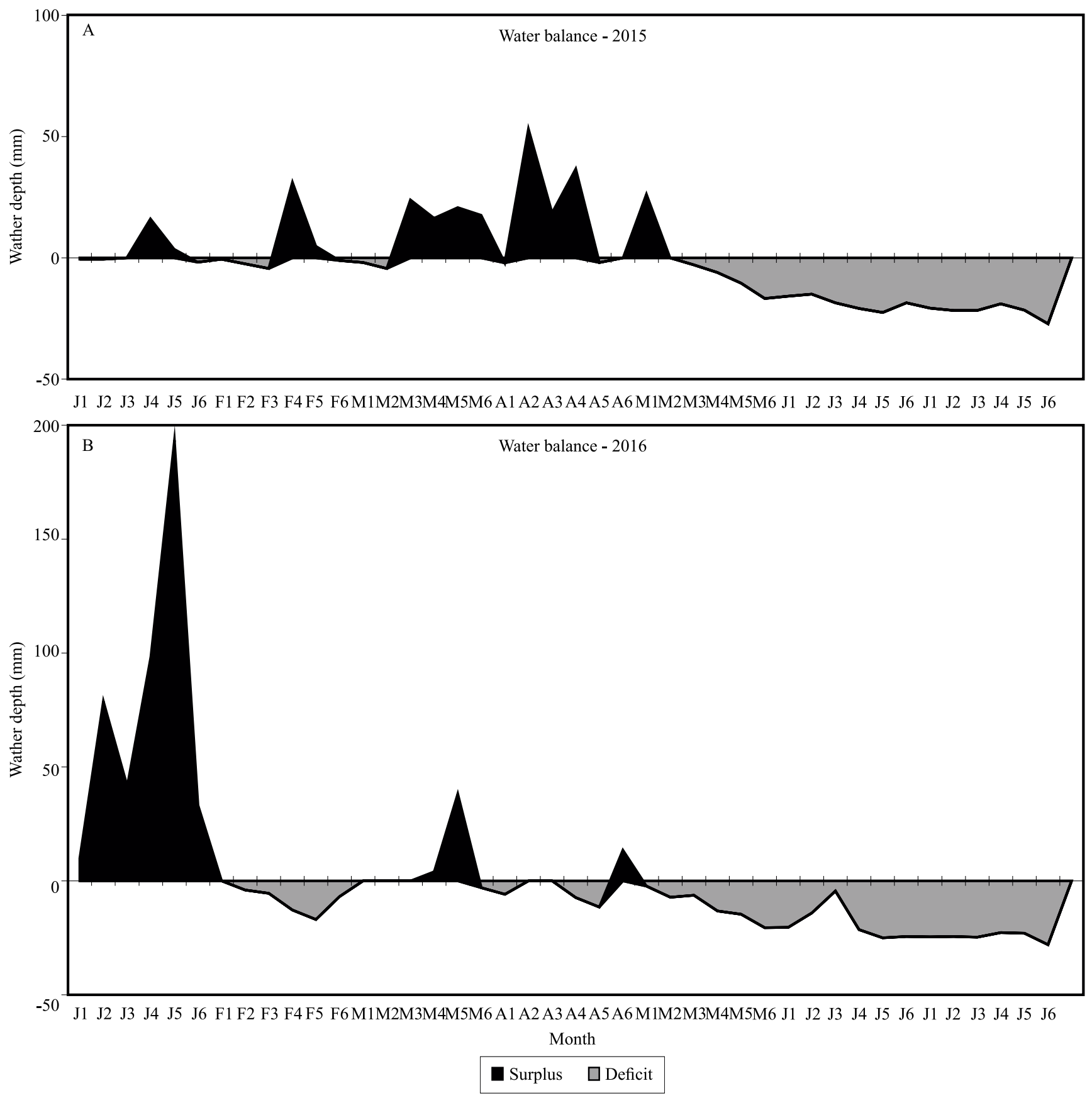

Figure 1. Soil water balance evaluated every 5 days from January to July, in 2015 (A) and 2016 (B), for corn (Zea mays) cultivated as an off-season crop in the experimental area in the municipality of Pedro Afonso, in the state of Tocantins, Brazil. 
water deficiency is detected from the end of April to the beginning of May, as observed in the water balance for 2015 (Figure 1 A). This explains the need to sow corn as soon as possible after harvesting of the summer crop, in order to avoid drought in the reproductive phases. It should be highlighted that the period and magnitude of water deficiency were greater in 2016 due to the rainfall volumes that were above average only in January, followed by dry months. This can be explained by the occurrence of a strong "El Niño" in 2016, which reduced precipitation volume and caused higher temperatures in those months, leading to greater stalk rot losses during the year.

When comparing two cultivars with similar productive potential during both experimental years, i.e., DKB 350 PRO in 2015 and P30S31 YH in 2016 (Table 2), greater losses were observed in the latter, 26.9 vs. $34.3 \%$, respectively (Table 1). This agrees with the concept that photosynthetic stress/translocation balance predisposes corn to stalk rot (Dodd, 1977), since, under stress condition, there is a marked reduction in plant photosynthetic capacity, which changes the translocation balance of photoassimilates, removing sugars from the stalk and directing them to the grains. Therefore, the greatest losses observed in 2016 are probably related to the occurrence of water stress, which predisposed the plants to pathogen infections. According to Leopold (1961), in areas where corn nutritional demand is adequately supplied and the demand and supply of carbohydrates to stalks and ears is balanced, there is a reduction in stalk rot incidence or a delay in the appearance of symptoms on plants.

In addition to water deficiency, other stress factors are common during the off-season, such as high nocturnal temperatures and the occurrence of cloudy days during the growing season, which may be responsible for the high incidence of stalk rot in the off-season crop.

The major fungal pathogens isolated from the stalk rot sampled in 2015 were $F$. graminearum, Stenocarpella maydis (Syn. Diplodia maydis), and $M$. phaseolina, with average frequencies of 65.6, 48.9, and 10\%, respectively (Figure 2). The LG 6036 PRO,

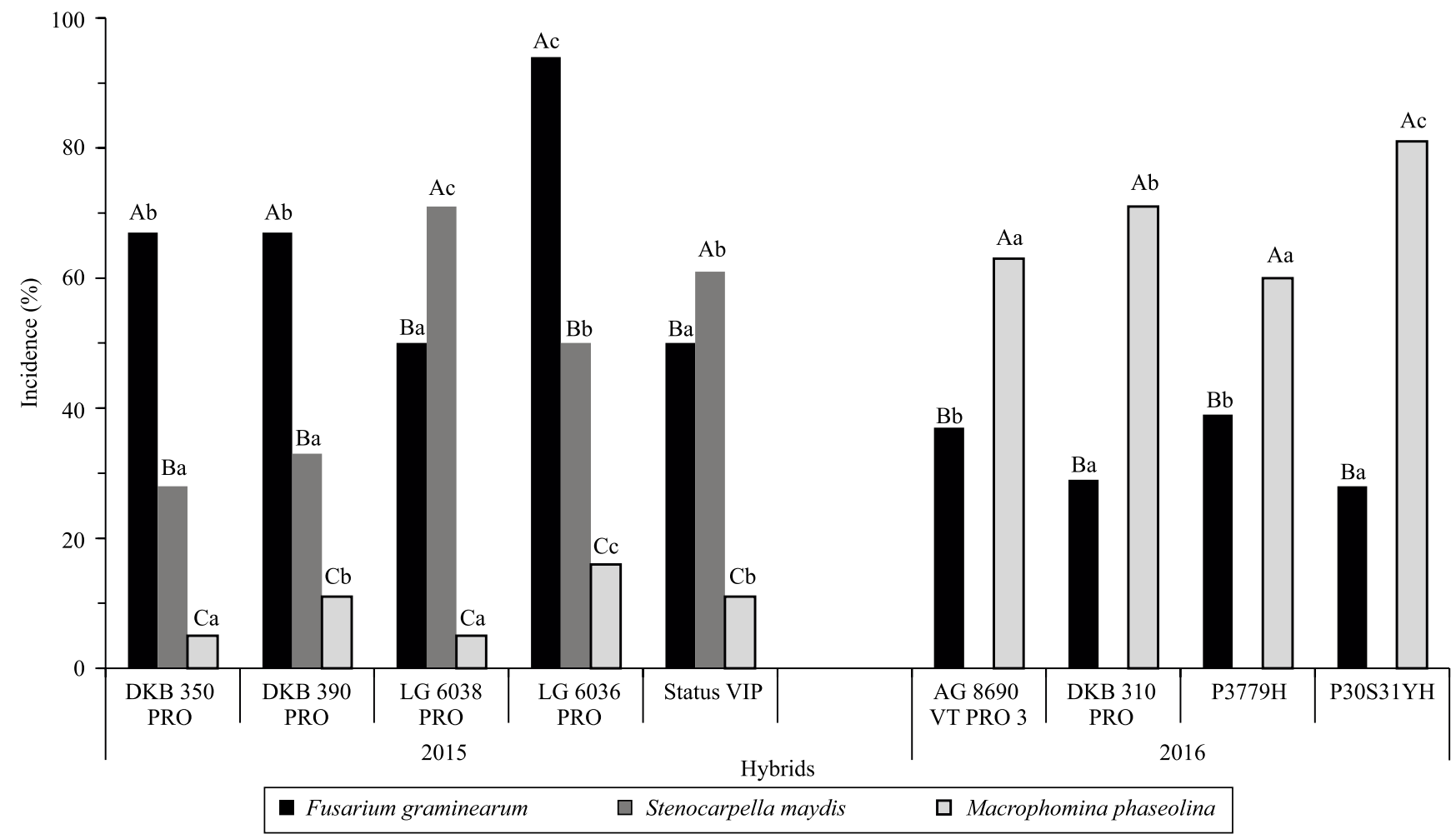

Figure 2. Incidence of stalk rot fungi in corn (Zea mays) hybrids cultivated in the off-season in 2015 and 2016. Bars followed by equal letters do not differ by the Scott-Knott test, at 5\% probability. Capital letters compare fungi incidence in each hybrid, and lowercase letters, incidence between hybrids. 
DKB 350 PRO, and DKB 390 PRO hybrids showed a high prevalence of $F$. graminearum, with an average incidence of 94,67 , and $67 \%$, respectively. However, in the LG 6038 PRO and Status VIP hybrids, the prevalent fungus was $S$. maydis, with incidences of 71 and $60 \%$, respectively. In 2016 , the predominant species were M. phaseolina and F. graminearum (Figure 2). In all hybrids, the frequency of $M$. phaseolina was significantly higher than that of $F$. graminearum; the fungus $S$. maydis, however, was not detected. These results agree with the literature, showing the importance of these fungi species as causing agents of corn stalk rot in Brazil. The main fungi species detected in a survey of stalk rot fungi in the Southern region of the country were $C$. graminicola and $F$. graminearum (Denti \& Reis, 2003). Moreover, other species, such as D. maydis, Diplodia macrospora, Fusarium moniliforme, and Fusarium subglutinans, were also identified. Similar results were obtained in other studies (Fontoura et al., 2006; Mir et al., 2018).

The predominance of stalk rot fungi is directly related to the plant genotype and to prevailing climatic conditions. Therefore, the prevalence of M. phaseolina in 2016 is probably due to the prolonged periods of drought and high temperatures recorded during most of the corn cycle. According to Kendig et al. (2000), the occurrence of $M$. phaseolina is strongly related to dry and hot periods during the growing cycle of the crop. Bandara et al. (2015) pointed out that prolonged exposure to drought stress and high temperatures during the grain-filling stage increase the incidence of stalk rot by $M$. phaseolina. However, stalk rot by Fusarium spp. is typically more severe when those stresses are followed by moisture conditions and mild temperatures near physiological maturation (Zummo, 1980). In 2015, with climatic conditions closer to the normality for the region, i.e., higher humidity and milder temperatures than in 2016, F. graminearum and $S$. maydis predominated.

\section{Conclusions}

1. Stalk rot is an important factor limiting the yield of the off-season corn (Zea mays) crop.

2. Corn hybrids with greater yield potentials suffer the greatest yield losses, probably due to the greater drain force of their ears.
3. The occurrence of water stress favors the incidence of the disease, causing greater yield losses.

4. The main stalk rot fungi identified in the offseason of corn cultivated in the state of Tocantins, Brazil, are: Fusarium graminearum, Stenocarpella maydis, and Macrophomina phaseolina.

\section{Acknowledgments}

To Embrapa Aquicultura e Pesca and to Embrapa Milho e Sorgo, for financial support.

\section{References}

ALVARES, C.A.; STAPE, J.L.; SENTELHAS, P.C.; GONÇALVES, J.L. de M.; SPAROVEK, G. Köppen's climate classification map for Brazil. Meteorologische Zeitschrift, v.22, p.711-728, 2013. DOI: https://doi.org/10.1127/09412948/2013/0507.

ARAKAKI, A.M.; MINUZZI, R.B. Datas de semeadura para o cultivo em sucessão soja-milho safrinha baseadas na produtividade para as regiões de Maringá-PR e Chapecó-SC. Revista Brasileira de Agropecuária Sustentável, v.6, p.11-18, 2016.

BANDARA, Y.M.A.Y.; PERUMAL, R.; LITTLE, C.R. Integrating resistance and tolerance for improved evaluation of sorghum lines against Fusarium stalk rot and charcoal rot. Phytoparasitica, v.43, p.485-499, 2015. DOI: https://doi.org/10.1007/s12600-0140451-0.

CARDOSO, C.O.; FARIA, R.T. de; FOLEGATTI, M.V. Simulação do rendimento e riscos climáticos para o milho safrinha em Londrina-PR, utilizando o modelo Ceres-Maize. Engenharia Agrícola, v.24, p.291-300, 2004. DOI: https://doi.org/10.1590/ S0100-69162004000200007.

CARSON, M.L.; HOOKER, A.L. Inheritance of resistance to anthracnose leafblight in five inbred lines of corn. Phytopathology, v.71, p.488-491, 1981. DOI: https://doi.org/10.1094/Phyto-71-488.

CASA, R.T.; MOREIRA, E.N.; BOGO, A.; SANGOI, L. Incidência de podridões do colmo, grãos ardidos e rendimento de grãos em híbridos de milho submetidos ao aumento na densidade de plantas. Summa Phytopathologica, v.33, p.353-357, 2007. DOI: https://doi.org/10.1590/S0100-54052007000400006.

CASELA, C.R.; FERREIRA, A. da S.; PINTO, N.F.J. de A. Doenças na cultura do milho. Sete Lagoas: Embrapa Milho e Sorgo, 2006. 14p. (Circular técnica, 83).

ACOMPANHAMENTO DE SAFRA BRASILEIRA [DE] GRÃOS: safra 2017/18: sexto levantamento, v.5, n.6, mar. 2018. Available at: <http://www.conab.gov.br/OlalaCMS/uploads/ arquivos/18_03_09_14_46_58_grao_marco_2018.pdf Accessed on: Mar. $\overline{12} 2018$.

COSTA, R.V. da; FERREIRA, A. da S.; CASELA, C.R.; SILVA, D.D. da. Podridões fúngicas de colmo na cultura do milho. Sete Lagoas: Embrapa Milho e Sorgo, 2008. 8p. (Circular técnica, 100). 
COSTA, R.V. da; SILVA, D.D. da; COTA, L.V.; PARREIRA, D.F.; FERREIRA, A. da S.; CASELA, C.R. Incidência de Colletotrichum graminicola em colmos de genótipos de milho. Summa Phytopathologica, v.36, p.122-128, 2010. DOI: https://doi.org/10.1590/S0100-54052010000200003.

COTA, L.V.; COSTA, R.V. da; SILVA, D.D.; CASELA, C.R.; PARREIRA, D.F. Quantification of yield losses due to anthracnose stalk rot on corn in Brazilian conditions. Journal of Phytopathology, v.160, p.680-684, 2012. DOI: https://doi. org/10.1111/jph.12008.

CHRISTENSEN, J.J.; WILCOXSON, R.D. Stalk rot of corn. Worcester: American Phytopathological Society at Heffernan Press, 1966. 59p.

DARRAH, L.L.; MCMULLEN, M.D.; ZUBER, M.S. Breeding, genetics, and seed corn production. In: WHITE, P.J.; JOHNSON, L.A. (Ed.). Corn: chemistry and technology. $2^{\text {nd }}$ ed. St. Paul: American Association of Cereal Chemists, 2003. p.35-68.

DENTI, E.A.; REIS, E.M. Levantamento de fungos associados às podridões do colmo e quantificação de danos em lavouras de milho do Planalto Médio Gaúcho e Campos Gerais do Paraná. Fitopatologia Brasileira, v.28, p.585-590, 2003. DOI: https://doi.org/10.1590/S0100-41582003000600001.

DHINGRA, O.D.; SINCLAIR, J.B. Basic plant pathology methods. $2^{\text {nd }}$ ed. Boca Raton: CRC Press, 1995. 434p.

DIOURTE, M.; STARR, J.L.; JEGER, M.J.; STACK, J.P.; ROSENOW, D.T. Charcoal rot (Macrophomina phaseolina) resistance and the effects of water stress on disease development in sorghum. Plant Pathology, v.44, p.196-202, 1995. DOI: https://doi.org/10.1111/j.1365-3059.1995.tb02729.x.

DODD, J.L. A photosynthetic stress-translocation balance concept of corn stalk rot. ANNUAL CORN AND SORGHUM RESEARCH CONFERENCE, 32., 1977, Chicago. Proceedings. Washington: American Seed Trade Association, 1977. p.122-130.

DODD, J.L. Grain sink size and predisposition of Zea mays to stalk rot. Phytopathology, v.70, p.534-535, 1980a. DOI: https://doi.org/10.1094/Phyto-70-534.

DODD, J.L. The role of plant stresses in development of corn stalk rots. Plant Disease, v.64, p.533-537, 1980b.

GATCH, E.W.; HELLMICH, R.L.; MUNKVOLD, G.P. A comparison of maize stalk rot occurrence in $\mathrm{Bt}$ and nonBt hybrids. Plant Disease, v.86, p.1149-1155, 2002. DOI: https://doi.org/10.1094/PDIS.2002.86.10.1149.

FONTOURA, D. da; STANGARLIN, J.R.; TRAUTMANN, R.R.; SCHIRMER, R.; SCHWANTES, D.O.; ANDREOTTI, M. Influência da população de plantas na incidência de doenças de colmo em híbridos de milho na safrinha. Acta Scientiarum. Agronomy, v.28, p.545-551, 2006. DOI: https://doi.org/10.4025/ actasciagron.v28i4.896.

JACKSON-ZIEMS, T.A.; REES, J.M.; HARVESON, R.M. Common stalk rot diseases of corn. Lincoln: University of Nebraska-Lincoln Extension, 2014. 8p. EC1898.

KENDIG, S.R.; RUPE, J.C.; SCOTT, H.D. Effect of irrigation and soil water stress on densities of Macrophomina phaseolina in soil and roots of two soybean cultivars. Plant Disease, v.84, p.895900, 2000. DOI: https://doi.org/10.1094/PDIS.2000.84.8.895.

KAPPELMAN, A.J.; THOMPSON, D.L. Inheritance of resistance to Diplodia stalk-rot in corn. Crop Science, v.6, p.288-290, 1966. DOI: https://doi.org/10.2135/ cropsci1966.0011183X000600030022x.

KHOKHAR, M.K.; HOODA, K.S.; SHARMA, S.S.; SINGH, V. Post flowering stalk rot complex of maize - present status and future prospects. Maydica, v.59, p.226-242, 2014.

LEOPOLD, A.C. Senescence in plant development. Science, v.134, p.1722-1732, 1961. DOI: https://doi.org/10.1126/ science.134.3492.1727.

LESLIE, J.F.; SUMMERELL, B.A. The Fusarium laboratory manual. Ames: Blackwell Publishing, 2006. 388p. DOI: https://doi.org/10.1002/9780470278376.

MIR, Z.R.; SINGH, P.K.; ZAIDI, P.H.; VINAYAN, M.T.; SHARMA, S.S.; KRISHNA, M.K.; VEMULA, A.K.; RATHORE, A.; NAIR, S.K. Genetic analysis of resistance to post flowering stalk rot in tropical germplasm of maize (Zea mays L.). Crop Protection, v.106, p.42-49, 2018. DOI: https://doi.org/10.1016/j. cropro.2017.12.004.

NAZARENO, N.R.X. Avaliação de perdas por podridão do colmo em milho (Zea mays L.) no Estado do Paraná. Fitopatologia Brasileira, v.14, p.82-84, 1989.

NICOLI, A.; ZAMBOLIM, L.; COSTA, R.V. da; GUIMARÃES, L.J.M.; LANZA, F.E.; SILVA, D.D. da; COTA, L.V. Identification of sources of resistance to anthracnose stalk rot in maize. Ciência Rural, v.46, p.1885-1890, 2016. DOI: https://doi.org/10.1590/0103$8478 \mathrm{cr} 20151052$.

REIS, E.M.; CASA, R.T.; BRESOLIN, A.C.R. Manual de diagnose e controle de doenças do milho. Lages: Graphel, 2004. 141p.

ROLIM, G. de S.; SENTELHAS, P.C.; BARBIERI, V. Planilhas no ambiente EXCEL $^{\mathrm{tm}}$ para os cálculos de balanços hídricos: normal, sequencial, cultura e de produtividade real e potencial. Revista Brasileira de Agrometeorologia, v.6, p.133-137, 1998.

SANTOS, H.G. dos; JACOMINE, P.K.T.; ANJOS, L.H.C. dos; OLIVEIRA, V.A. de; LUMBRERAS, J.F.; COELHO, M.R.; ALMEIDA, J.A. de; CUNHA, T.J.F.; OLIVEIRA, J.B. de. Sistema brasileiro de classificação de solos. 3.ed. rev. e ampl. Brasília: Embrapa, 2013. 353p.

SCOTT, S.W.; GRIFFITHS, E. Effects of controlled epidemics of powdery mildew on grain yield of spring barley. Annals of Applied Biology, v.94, p.19-31, 1980. DOI: https://doi. org/10.1111/j.1744-7348.1980.tb03892.x.

SUTTON, B.C. The Coelomycetes: fungi imperfecti with Pycnidia, Acervuli and Stromata. Kew: Commonwealth Mycological Institute, 1980. 696p.

TOMAN JR., J.; WHITE, D.G. Inheritance of resistance to anthracnose stalk rot of corn. Phytopathology, v.83, p.981-986, 1993. DOI: https://doi.org/10.1094/Phyto-83-981.

VINCELLI, P.; HERSHMAN, D.E. Corn stalk rots. Kentucky: University of Kentucky, 1985. 5p. (Agriculture and Natural Resources Publications, 42). 
MUNKVOLD, G.P.; WHITE, D.G. (Ed.). Compendium of corn diseases. $3^{\text {rd }}$ ed. St Paul: APS Press, 1999. 78p.

WHITE, D.G., YANNEY, J.; NATTI, T.A. Anthracnose stalk rot. In: ANNUAL CORN AND SORGHUM RESEARCH CONFERENCE, 34., 1979, Chicago. [Washington]: American Seed Trade Association, 1979. p.1-15.

YANG, Q.; YIN, G.; GUO, Y.; ZHANG, D.; CHEN, S.; XU, M. A major QTL for resistance to Gibberella stalk rot in maize. Theoretical and Applied Genetics, v.121, p.673-687, 2010. DOI: https://doi.org/10.1007/s00122-010-1339-0.
YANG, D.E.; JIN, D.M.; WANG, B.; ZHANG, D.S.; NGUYEN, H.-T.; ZHANG, C.L.; CHEN, S.J. Characterization and mapping of Rpil, a gene that confers dominant resistance to stalk rot in maize. Molecular Genetics and Genomics, v.274, p.229-234, 2005. DOI: https://doi.org/10.1007/s00438005-0016-5.

ZUMMO, N. Fusarium disease complex of sorghum in West Africa. In: INTERNATIONAL WORKSHOP ON SORGHUM DISEASES, 1978, Hyderabad. Proceedings. Hyderabad: ICRISAT, 1980. p.297-299. Editor: G. D. Bengtson. 